\title{
ДИАЛЕКТНАЯ ЛЕКСЕМА РЕЛЬ В РУССКОЙ ОНОМАСТИКЕ
}

\section{Dialect Lexeme "рель" in the Russian Onomastics}

Keywords: onomastics, onomatology, toponymy, microtoponymy, dialectology, etymology

Contact: МГОУ; ars-romano@yandex.ru

В русских народных говорах достаточно широко распространена лексема рель и ее дериваты. Являясь диалектной лексемой с выраженной простраственной семантикой, она закономерно выступает в роли топонимических и микротопонимических единиц на территории средней полосы России, что соответствует географии распространения древнерусского фонда диалектной лексики. Вообще, тема представления диалектных лексем в русской топонимии актуальна и неустанно изучается, одной из самых масштабных работ в этой области является «Словарь народных географических терминов» Э. М. Мурзаева. При углубленном изучении истории и диалектной специфики лексемы рель мы столкнулись с отсутствием исследований на эту тему. Восполнение любого зияния на поле ономастических исследований пополняет научный арсенал этнолингвистики и этнопсихологии, так как раскрывает традиционные сферы народной культуры.

Целью данной работы является изучение представления лексемы рель в русских диалектах; развития семантики лексемы при переходе из диалектов в микротопонимию и топонимию; ее распространение в качестве топонима. В ходе исследования использовались материалы диалектных, этимологических и языковых словарей, электронных географических карт, научная и художественная литература.

Данная работа является результатом исследований, проведенных Лабораторией палеолингвистики и региональной лексикографии под руководством А. В. Войтенко. 
Говоря о представлении лексемы рель в русских народных говорах, необходимо очертить круг ее значений и перечислить ее дериваты: релка, релочка, релушечка, релушка, рела, релина, ролка, реличка, релька, рела, релья, рель, рели, релины, ориолка, риолка, орелок, релок, релица, рела, релец, релка, релки, рело, релошная (сущ.), релье, рельи, рельице, рельна, рельня, рельцьи, релюшки. Они имеют сто тридцать значений (см. Приложение), в которых выделяются семы изменения высоты рельефа, его отклонения от ровной поверхности: кочка на болоте, возвышенное место на берегу; удлиненной, продолговатой формы: жердь, тонкое бревно, шест, веревка для сушки белья. В некоторых случаях эти семы сочетаются: узкая полоска сухой земли среди большой лужи или болота, участок (чаще сенокоса) в форме длинной узкой полосы, часто заливаемой в половодье. Кроме того, лексема обнаруживается в древнерусском и церковнославянском языках, имея в своих значениях (отмель, перекладина и т. д.) те же семы. А также употребляется в русской литературе в следующих значениях: качели, на которых спускаются (по русскому мифологическому представлению) в подземное царство, ремни, полотно и канаты для той же цели (Дьяченко 1900: 547); виселица: «- Вон, гляди, им уж рели построили, - указал он на виселицу, устроенную между двух чахлых верб» (Шолохов, 1928-1929: 48).

Основываясь на полученных данных, все значения лексемы рель можно разделить на две семантические группы:

1. участки земли / особенности рельефа, содержащие сему выделения по высоте;

2. продолговатые, вытянутые, прямые предметы: столбы, жерди, веревки и т. д.

Эти группы могут пересекаться, включая в себя оба значения: продолговатый, прямой участок земли, полоса.

В диалектных словарях можно встретить также лексему «рельса», имеющую сему 'продолговатый предмет, перекладина', в значении 'брус, который кладут поперек стропил', эту же сему содержит слово «рельса» в общеупотребительном значении, что дает повод предполагать связь лексем рель и «рельса». Продолжая рассуждения на эту тему, нельзя не отметить наличие варианта рилинь с «и» в первом слоге в псковском варианте слова, которое, возможно, является рефлексом Ђ и может указывать на его связь с дифтонгом «аі» в слове «rails». О присутствии Ђ в древней форме корня говорит и наличие лексемы рілля в значении 'пашня, вспаханное поле' (Білодід 1970-1980: 575). 
Тем не менее, не следует делать вывод, что «рельс» и реля - родственные слова. Реля, как упоминалось ранее, является древнерусским словом, «рельс» же, согласно «Этимологическому словарю русского языка» М. Фасмера, было заимствовано в XIX в. из английского языка («rails»), причем в форме ж. p., сохраняя флексию -s, - «рельса». Тем не менее, по данным словарей М. Фасмера и М. де Ваана, «rails» восходит к праиндоевропейскому корню *reg-, обозначающему 'растягивать, прямой', содержащему ту же сему, что и рель (Фасмер 1987: 467), (Vaan 2008: 517-518). Это может послужить поводом для этимологических исследований.

Не утрачивая вышеупомянутые семы, лексема распространяется в микротопонимии России. Например, в Новгородской области существуют Дальняя Релка - возвышенное место в лесу - и Голубиная Рель - пашня. Не утрачивает она их и при распространении в топонимии. Из материалов «Топонимического словаря Центральной России» Г. П. Смолицкой следует, что слово рель довольно активно в топонимии северо-запада Центральной России (Смолицкая 2002: 283-284). Анализ интернет-карт «Яндекс.Карты» и «OpenStreetMap» дает следующие результаты:

1. Деревня Рель. Осьминское сельское поселение, Лужский район, Ленинградская область, Россия. 58.959773, 28.928401.

2. Деревня Релка. Осьминское сельское поселение, Лужский район, Ленинградская область, Россия. 58.990916, 28.976426.

3. Острова Алехина Релка. Вышневолоцкий городской округ, Тверская область, Россия 57.609302, 34.462824.

4. Деревня Релка. Муниципальное образование Город Березники, Пермский край, Россия. 59.633134, 56.013991.

5. Деревня Релка. Вагайский район, Тюменская область, Россия. 57.965785, 69.374347.

6. Остров Большой Рель. Вырицкое городское поселение, Гатчинский район, Ленинградская область, Россия. 59.034945, 30.207702.

7. Деревня Релка. Дедовичский район, Псковская область, Россия. 57.572800, 29.978470 .

8. Большая Релка. Крестецкий район, Новгородская область, Россия. 58.372469, 32.315644. 
9. Малая Релка. Крестецкий район, Новгородская область, Россия. 58.372002, 32.320728 .

10. Остров Кунина Релка. Вышневолоцкий городской округ, Тверская область, Россия. 57.602913, 34.464647.

11. Остров Жаровинская Релка. Муниципальное образование Холмогорское, Холмогорский район, Архангельская область, Россия. 64.300280, 41.514877.

12. Урочище Остров Релка. Виноградовский район, Архангельская область, Россия. 62.564190, 43.652832.

13. Деревня Зарелье. Новгородский район, Новгородская область, Россия. $58.582510,31.404815$.

14. Село Подрелье. Орловский район, Кировская область, Россия. 58.677490, 49.16834 (Яндекс.Карты), (OpenStreetMap).

Как видно из полученных данных, основа рель действительно довольно активна в топонимии запада России. В намного меньшем количестве встречается она на востоке Сибири, причем исключительно в виде гидронимов:

1. Река Рель. Северо-Байкальский район, Республика Бурятия, Россия. 55.419784, 108.861799.

2. Река Голая Релка. Киренский район, Иркутская область, Россия. 57.331922, 107.830802 .

3. Река Релка. Таймырский Долгано-Ненецкий район, Красноярский край, Россия. 70.939236, 111.109860 (Яндекс.Карты), (OpenStreetMap).

Как было сказано, в приведенных выше онимах выделяются две основные семы: возвышение / понижение рельефа и удлиненный, продолговатый предмет (в данном случае - участок земли). Причем в топонимии более ярко представлено второе значение: все географические объекты, которые изображены на карте детально, имеют «продолговатый» внешний вид: деревни состоят из домов, стоящих вдоль длинной основной улицы; острова имеют удлиненную тонкую форму. Интереснее ситуация с д. Зарелье и с. Подрелье: первая окружена продолговатыми озерами и полосками леса, кроме того, находится у реки. Исходя из картографических фактов, наиболее вероятным представляется получение такого названия из-за нахождения за релкой леса относительно соседней деревни (Хутынь). Второе же находится у маленькой речки, отделяющей его от д. Заовраг, а также неподалеку от полосы леса. Скорее всего, топоним Заовраг появился 
позже и обозначает нахождение деревни за оврагом по отношению к селу. Изначально же овраг назывался релью, а село находилось «под» ней.

Итак, нами было проанализировано 132 значения диалектизма рель. Каждое из них принадлежит к одной из (или к обеим) следующих семантических групп: участки земли / особенности рельефа, содержащие сему выделения по высоте; продолговатые, вытянутые, прямые предметы: столбы, жерди, веревки и т. д. Он редко встречается в художественной литературе, но распространен русской мифологии. Лексема рель активно используется в диалектах, микротопонимии и топонимии западной части России (в Ленинградской, Пермской, Тюменской, Тверской, Кировской и др. областях), его появление неподалеку от Байкала (в Иркутской области, Красноярском крае и Республике Бурятии) в качестве гидронима, скорее всего, связано с освоением Байкала. Данные исторических словарей и их соотнесение с современными значениями диалектизма позволяют предполагать, что слово рель является исконно русским словом и ставит вопрос о его этимологической связи со словом «рельс», что предполагает дальнейшие исследования происхождения данной лексемы.

\section{Summary}

We analyzed 132 values of dialectal lexeme рель. It is rarely found in literature, but is common in Russian mythology. The lexeme is widely used in dialects, microtoponymy and toponymy of the Western part of Russia. Its appearance near Lake Baikal as a hydronym is most likely connected with the development of Lake Baikal. Data from historical dictionaries and their correlation with modern dialectical meanings allow us to suggest that the word рель included in the aboriginal Russian vocabulary and raises the question of its etymological connection with the word "rail".

\section{Литература}

Білодід, І. Словник української мови: в 11 mm. T. 7. Київ: Наукова думка, 19701980.

Борисова, А. Словарь пермских говоров. Bыл. 2. Пермь: Книжный мир, 2000.

Бородина, М. Ярославский областной словарь: Питок-Ряшка. Ярославль: ЯГПИ, 1989.

Востоков, А. Словарь церковно-славянского языка. T. 4. Санкт-Петербург: Императорская Академия Наук, 1847. 
Ганцовская, Н. Костромские говоры, учебный комплекс: в 2-х m. Кострома: Издательство КГУ, 2018.

Герд, А. Словарь русских говоров Карелии и сопредельных областей в 6 выn. Bbыn. 5: Подузорье-свильнуть. Санкт-Петербург: Издательство СПбГУ, 2002.

Даль, В. Толковый словарь живого великорусского языка. T. 4: P-V. СанктПетербург: М. О. Вольф.

Дьяченко, Г. Полный цеерковно-славянский словарь (со внесением в него важнейших древне-русских слов и выражений), содержащчй в себе объяснения малопонятных слов и оборотов, встречающихся в иерковнославянских и древне-русских рукописях $и$ книгах: пособие для преподавателей русскаго и изерковно-славянскаго яз. в низших и средних учебных заведениях...: всех слов объяснено около 30 000. Москва: Типография Вильде, 1900.

Левичкин, А. Новгородский областной словарь. Санкт-Петербург: Наука, 2010.

Мурзаев, Э. Словарь народных географических терминов. Москва: Мысль, 1984.

Новикова, Л. Селигер: материалы по русской диалектологии: словарь. Bып. 6: Р. Санкт-Петербург: Издательство СПбГУ, 2014.

Паникаровская, Т. Словарь вологодских говоров. Bыл. 9. Вологда: ООО Графика, 2002.

Сороколетов, Ф. П. (гл. ред.) Словарь русских народных говоров. Bыл. 35: Реветь-Рящик. Санкт-Петербург: Издательство «Наука», 2001.

Смолицкая, Г. Топонимический словарь Центральной России. Москва: Армадапресс, 2002.

Срезневский, И. Материалы для Словаря древне-русскаго языка по письменным памятникам. T. 3: Р-НА (йотированный юс мальй) и дополнения. СанктПетербург: Отделение русского языка и словесности Императорской Академии Наук, 1903-1912.

Тиханов, П. Брянский говор: Заметки из области русской этнологии. СанктПетербург: Типография Императорской Академии Наук, 1904.

Толстой, Н. (общ. ред.) Славянские древности: Этнолингвистический словарь. T. 4: П (Переправа через воду)-C (Сито). Москва: Международные отношения, 2009. 
Фасмер, М. Этимологический словарь русского языка. В 4 т. Т. 3: Муза-Сят. Москва: Прогресс, 1987.

Шолохов, М. Тихий Дон. Ч. 5: Кровь под копьтом. Роман-газета. Москва: Московский рабочий, 1928-1929.

Vaan, M. de. Etymological dictionary of Latin and the other Italic languages. Leiden, Boston: Brill, 2008.

\section{Интернет-источники}

Режим доступа: https://www.openstreetmap.org (2020-02-20).

Режим доступа: https://yandex.ru/maps (2020-02-20).

\section{Приложение}

Круг значений лексемы рель (Борисова 2002: 287-288, Бородина 1989: 131, Ганцовская 2018: 168, Герд 2002: 513, Даль 1882: 91-92, Левичкин 2010: 1023-1028, Мурзаев 1984: 330, Новикова 2014: 77, Паникаровская 2002: 50-51, СРНГ 2001: 46-51, Тиханов 1904: 76-77):

1. Болотный луг. (Новг.)

2. Болото между полей. (Новосиб.)

3. Болото. (Новг., Волог.)

4. Большая полоса луга. (Тверск.)

5. Валок сена. (Новг., Псков.)

6. Веревка для сушки белья. (Костр.)

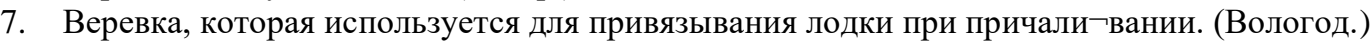

8. Виселица. (Брянск., Перм., Казан., Смол., Урал., Ряз., Якут., Колым., Ленингр., Свердл., Тул., Арх., Карел., Сарат., Онеж. былины., Даль)

9. Возвышенное место в лесу, в поле, среди болота. (Вологод., Новг., Перм., Карел.)

10. Возвышенное место в лесу, заросшее ельником. (Вологод., Новг.)

11. Возвышенное место в русле реки, отмель. (Вологод. Новг., Карел.)

12. Возвышенное место на берегу. (Беломор.)

13. Возвышенное сухое место на болоте или в сыром лесу. (Подмоск., Свердл., Даль)

14. Возвышенность между оврагами. (Перм.)

15. Возвышенность на лугу. (Забайкалье.)

16. Возвышенность, холм, обычно продолговатая гряда среди равнины или в лесу. (Вост., Север., Сиб., Карел., Перм., Краснояр., Арх., Псков., Амур., Хабар., Свердл., Вологод., Калин., Киров.)

17. Возвышенный участок поля, не затопляемый при разливе. (Забайкалье.)

18. Вырубка в лесу. (Калин., Свердл.)

19. Высокая, с острой вершиной гора (Арх.)

20. Высокие перила, поручни, ограда. (Ряз., Даль)

21. Гряда с пологими склонами. (Бурят.)

22. Грядка на огороде. (Краснояр.)

23. Два столба с перекладиной для детских качелей. (Новг.)

24. Дерево или небольшая группа деревьев, а также несколько домов, стоящих отдельно от других деревьев, домов. (Новосиб., Свердл., Амур.)

25. Деревянная рейка, планка. (Карел.)

26. Деревянные планки для сидения на телеге, прибитые к ее краям. (Пск.)

27. Деревянный брус. (Новг., Карел.)

28. Длинное бревно в основании мельничной плотины. (Новг.)

29. Длинный шест у колодца, употребляемый как рычаг для подъема воды. (Карел., Тверск., Ряз.) 
30. Жердина для перехода через ручей. (Новг.)

31. Жердочка на двух веревках в избе для сушки белья, рыбы и т.п. (Новг.)

32. Жердь длиной в пятнадцать метров для прогона невода при подледном лове рыбы. (Новг., Псков., Калин., Север., Вост.)

33. Жердь, к которой крепится сиденье качелей. (Вологод., Новг.)

34. Жердь, тонкое бревно, шест. (Новг., Арх., Север., Вост., Тверск., Орл., Даль)

35. Заболоченная низина около реки. (Вологод.)

36. Идущая грядой полоса земли, отличающаяся растительностью, местоположением и др. от окружающей местности (Вост., Север., Сиб., Даль)

37. Каменистая мель на море, не обнажающаяся при отливе. (Мурманск.)

38. Каток, скалка. (Подмоск.)

39. Качели, сиденье которых прикреплено жердями. (Вологод.)

40. Качели. (Новг., Яросл., Тверск., Подмоск., Ряз, Моск., Псков., Ленингр., Печор., Влад., Нижегор., Казан., Пенз., Симб., Куйбыш., Калуж., Орл., Курск., Липецк., Тамб., Ворон., Дон., Сарат., Волгогр., Заволжье, Тул., Десна, Ока, Южн., Ставроп., Оренб., Том., Краснояр., Урал, Дон., Калуж.)

41. Косогор. (Перм.)

42. Кочка на болоте. (Новг.)

43. Красивое место, лужайка на берегу реки. (Арх.)

44. Кровать, сделанная из двух параллельно поставленных и скрепленных друг с другом скамеек, без спинок. (Яросл.)

45. Крутой берег на изгибе реки. (Яросл.)

46. Крутой, высокий берег реки. (Вологод., Яросл.)

47. Крутой, обрывистый склон горы, холма, берега. (Вологод.)

48. Лес, растущий на сухом, возвышенном месте, выделяющийся среди всего лесного массива, обычно лучший, строевой. (Ленингр.)

49. Лес. (Новг.)

50. Луг, поляна в лесу или на берегу реки. (Перм.)

51. Лужайка - ответвление от большого луга. (Тверск.)

52. Маленький песчаный остров. (Арх., Урал.)

53. Медная бляшка, соединяющая скрещенные на лбу лошади ремни узды. (Пск., Тверск., Даль)

54. Мелкое место на реке, перекат. (Свердл.)

55. Место у реки, освободившееся от воды и занимаемое для посадки капусты и т.п. (Новг.)

56. Мостки для перехода через реку. (Ленингр.)

57. Мостовая балка из дерева. (Новг.)

58. Мыс. (Новг.)

59. Наносная гряда вдоль берега реки, озера, обычно затопляемая весной. (Новг., Даль)

60. Небольшая возвышенность, пригорок. (Тверск.)

61. Небольшое поле. (Псков.)

62. Небольшой залив. (Тобол., Урал.)

63. Небольшой участок покоса около реки, леса. (Вологод., Костр., Новг.)

64. Невысокие незатопляемые гривы, заросшие часто лесной растительностью, среди затопленных лугов. (Дальн. Вост.)

65. Незначительная по высоте плоская гряда или вал. (бас. Анадыря)

66. Непропаханная полоса поля между двумя вспаханными участками. (Костр., Новг.)

67. Низкий берег с намытым песком. (Новг.)

68. Низкое, сырое место. (Карел., Урал.)

69. О высокой тонкой женщине. (Тверск.)

70. Обмелевшее место на реке, озере, поросшее травой, кустарником. (Карел.)

71. Обособленное или отделенное от других поле. (Калин.)

72. Обсохший край берега (Беломор.)

73. Одинокое дерево, растущее вблизи леса. (Новосиб., Свердл.)

74. Орудие для лова рыбы. (Новг.)

75. Остров. (Новг., Урал.)

76. Островок среди поа, поросший мелколесьем. (Забайкалье, Амур, Хабар.)

77. Островок, намытый рекой. (Вологод.)

78. Открытая ровная площадка на вершине сопки, холма. (Амур)

79. Пасхальное народное гуляние (во время пасхальных гуляний возводились качели - рели). (Южн.)

80. Пашня, пахотное поле. (Тверск.)

81. Перекладина у виселицы. (Онеж. былины.) 
82. Пересохший участок реки. (Яросл.)

83. Песчаная коса. (Новг.)

84. Песчаный бугор, заливаемый в высокую воду. (Север.)

85. Песчаный бугорок в мелководной реке. (Арх.)

86. Песчаный нанос продолговатой формы на реке, отмель. (Арх, Сев. Урал, Сиб., Новг., Оренб., Волог., Киров., Свердл., Курган., Том., Краснояр., Иркут., Беломор., Карел., Калин., Даль)

87. По народному поверью - крик русалок, качающихся на ветках деревьев. (Смол.)

88. Покос в низком, сыром месте. (Карел.)

89. Пологий склон горы, холма или берега реки. (Хабар.)

90. Полоса деревьев одной породы в лесу. (Тверск.)

91. Полоса посева. (Тверск.)

92. Поляна. (Вологод., Новг., Тверск., Перм., Урал., Свердл.)

93. Последнее (верхнее) бревно в строении. (Новг.)

94. Прибрежная отмель. (Беломор.)

95. Продолговатая возвышенность, грива. (Вологод., Даль)

96. Редколесье. (Амур.)

97. Релошный (лес) - строевой хвойный лес. (Новг.)

98. Речной мыс, песчаная коса. (Север, Оренб., Арх., Свердл., Даль)

99. Ровное, открытое, возвышенное место. (Арх., Свердл., Перм., Амур.)

100.Ровный лес. (Карел.)

101.Род переписи. (Даль)

102.Самодельные качели из веревок. (Костр.)

103.Сенокосный участок, луг. (Новг.)

104.Склон горы, холма, берега. (Вологод.)

105.Сооружение в озере, сделанное из длинных жердей и еловых веток, где ставятся мережки для ловли рыбы. (Яросл.)

106.Составная часть жнейки, сбрасывающая срезанные стебли. (Яросл.)

107. Составные части качелей — вер $\neg$ тикальные деревянные шесты или веревки, к которым прикрепляется сиденье. (Яросл., Брянск., Ряз.)

108.Столб, брус, жердь, служащие опорой чего-н. (Карел.)

109.Столбы у качелей. (Новг., Тверск., Ряз.)

110.Строевой хвойный лес. (Ленингр.)

111.Строительные леса, козлы, служащие подставкой, опорой для чего-либо. (Новг., Ряз., Даль)

112.Сухая тропинка, идущая по болоту. (Вост., Север., Сиб.)

113.Сухое возвышенное место, гряда, островок среди болота или низменной местности. (Север., Вост., Сиб., Беломор., Ленингр., Тверск., Арх., Перм., Киров., Моск., Мурманск., Свердл., Иркутск., Амур., Калин., Тобол., Хабар., Даль)

114.Сухое возвышенное место. (Карел., Арх.)

115.Сухое место в болоте, поросшее лесом. (Тверск., Амур., Забайкалье., Свердл.)

116.Тонкое, длинное бревно для настила потолка на скотном дворе или для укладки двойного (нижнего) пола. (Новг.)

117.Узкая возвышенность, окруженная водой, ручьями (Костр.)

118.Узкая полоска сухой земли среди большой лужи или болота. (Костр.)

119.Узкий полуостровок на реке, озере. (Новосиб.)

120.Упаковка яиц. (Тверск.)

121.Участок (чаще сенокоса) в форме длинной узкой полосы, часто заливаемой в половодье. (Новг.)

122.Участок земли (чаще пашни) удлиненной формы, обычно на возвышенном месте, отделенный от других естественными рубежами (лесом, болотом, ручьем и т.п.). (Новг.)

123.Участок земли на возвышении. (Яросл.)

124.Участок земли, отдаленный от других. (Калин.)

125.Участок земли, периодически затопляемый водой, низина у реки, луг на таком месте. (Перм., Тобол., Новг.)

126.Участок леса, обычно одной породы. (Новг.)

127.Участок луга, пашни на возвышенности. (Забайкалье, Яросл.)

128.Холм у слияния двух рек. (Беломор.)

129.Холмик, бугорок. (Перм.)

130.Целина, вспаханная первый раз. (Новг.)

131.Часть, полоса обрабатываемого участ ка земли, пашни, луга. (Калин., Ленингр., Псков., Тобол., Амур., Новг., Яросл.) 
132.Чистое, возвышенное место между двумя оврагами. (Перм.)

\section{Представление лексемы рель в древнерусском языке:}

1. Поемный луг. рьль = рель - заливная луговина, пожня:

Се азъ князь великыи В'севолодъ даль юсми святомоу Георгию рель отъ Волхова по крьстъ, по роучью въ Мячино. Грам. кн. Всевол. Юр. мон. д. 1136 г.

Се въдале Варламе $<\ldots>$ землю и огородъ и ловища рыбная и гоголина $\square$ и пожни: а. рьль против села за Волховомъ. Грам. Хут. п. 1192 г.

Рьлка (?) = рьлка - уменьшит. отъ рьль (?) - отмель:

Обрьте мъсто на Софъийской сторонъ, идъ же баня стоитъ на ргљлькъ; а ту рглльку преже изначала звали Крюкь, а на неи преже жили нарочитые дворяне владычня двора. Соф. вр. 1528 г. (т. II. 365, 366)

2. РБль - перекладина и рђнь - отмель.

Ръль (?) - перекладина; настилка мостовая: — Ана Волховъ вода была до релей мостовыхъ. Псков. I л. 7072 г.

— звено мостовое: — ИїВолоховьска $\square$ г-и риль, өТ $\square$ желбичка $\square$ двои рилґ. Уст. Яр. о мост.

— ср. рилинь (Срезневский 1912: 216)

Рилинь (?) - перекладина (?): — Того льта наяли Псковичи наимиты на новои мостовъ на Псковъ ръкъ, а запасъ балки наимитовъ, а рилини и городни и дубья Псковская. Псков. I л. 6943

г. (Срезневский 1912: 123)

\section{Представление лексемы рель в памятниках церковнославянской письменности:}

1. Рель («рли» в мн.ч.) - поемный луг: «Въ льто 1403 бысть вода суха и рли вси сухи быша.» И. Г. Р. V. 136.

2. Рели:

a. Два столба, соединенные перекладиною, качели: «Качаться на реляхъ».

b. Перилы: «На Волховђ вода была до релей мостовыхъ.» И. Г. Р. ІХ. прим. 33. (Востоков 1847: 62)

Представление лексемы рель в микротопонимии Новгородской области (Левичкин 2010: 1023-1028):

1. Аркадовская Релка. Возвышенное место у д. Аннино.

2. Афонина Релка. Возвышенное место в болоте у д. Видогощь.

3. Большая Релка. Пожня около д. Русско.

4. Бычковская Релка. Возвышенность у д. Аннино.

5. Вошивая Релка. Участок земли.

6. Глиническая Релка. Поле у д. Горнешно.

7. Глиническая Релка. Поле, на котором сеют рожь.

8. Горелая Релка. Лес.

9. Дальняя Релка. Возвышенное место в лесу.

10. Дубовая Релка. Место у реки; участок леса.

11. Замошечная Релка. Поле к западу от д. Козынево.

12. Кобылья Релка. Возвышенность у д. Славитино.

13. Марьина Релка. Место у д. Долгие Бороды.

14. Мошниковская Релка. Возвышенность на болоте.

15. Одоевская Релка.

16. Опуевская Релка. Место у д. Аннино.

17. Поперечная Релка. Место в лесу.

18. Попова Релка. Пашня у д. Хотяж; лесное угодье у п. Зарубино.

19. Релка. Место у д. Горки; сенокосный участок; участок леса у д. Новый Скребель; песчаный остров на реке у с. Залучье; рыболовная тоня; болото у д. Костьково; болото.

20. Середняя Релка. Пашня.

21. Солдатская Релка. Пашня у д. Подольская.

22. Токарева Релка. Участок земли у д. Семеновщина.

23. Фоминьиина Релка. Место у д. Хотяж.

24. Цыганская Релка. Место у д. Горки.

25. Черная Релка. Пашня у д. Лозницы.

26. Язвиная Релка. Возвышение среди болота у д. Видогощь. 
27. Антониевская Рель. Заливной луг у Донца и Волхова.

28. Голубиная Рель. Пашня.

29. Долбыиинская Рель. Покос.

30. Железинская Рель. Заливной луг.

31. Задняя Рель. Участок пашни у д. Высокое.

32. Каменная Рель. Заливной луг у д. Запростье.

33. Лебединая Рель. Место в Чагодовском озере.

34. Рель. Левый берег Волхова от Юрьева монастыря и до Кремля; место у д. Хотяж; поле; участок леса у д. Боровня; пахотная земля; сенокосное угодье у д. Перелучи.

35. Северная Рель. Участок поля у д. Голино.

36. Южская Рель. Участок поля у д. Голино.

37. Юрьевская Рель. Луг около Юрьева монастыря.

(c) $($ (i) $\bigcirc$ The article is accessible in open access mode under licence CC BY-NC-ND BY NC ND Creative Commons Attribution-NonCommercial-NoDerivatives 4.0 